\title{
Diurnal dynamic of inorganic carbon and oxygen dissolved in a Nile tilapia (Oreochromis niloticus Linnaeus, 1758) fish pond, São Paulo, Brasil
}

Dinâmica diurna das formas de carbono inorgânico e oxigênio dissolvido em viveiro de tilápias do Nilo (Oreochromis niloticus Linnaeus, 1758), São Paulo, Brasil

Claudinei José Rodrigues ${ }^{1}$, Cacilda Thais Janson Mercante ${ }^{2}$, Clovis Ferreira do Carmo², Andréa Tucci ${ }^{3}$, João Alexandre Savilo Osti², Ariane Carolina Di Genaro ${ }^{2}$

${ }^{1}$ Instituto Chico Mendes de Conservação da Biodiversidade - ICMBio, Rod. SC 402, Km 2, Jurere, CEP 88053-700, Florianopolis, SC, Brazil e-mail: claudinei.rodrigues@icmbio.gov.br

${ }^{2}$ Instituto de Pesca de São Paulo, Av. Francisco Matarazzo, 455, Parque da Água Branca, CEP 05001-000, São Paulo, SP, Brazil e-mail: cthais@pesca.sp.gov.br; clovis@pesca.sp.gov.br; jale.osti@gmail.com; arianegenaro@hotmail.com

${ }^{3}$ Instituto de Botânica, Seção de Ficologia, CP 4005, CEP 01061-970, São Paulo, SP, Brazil e-mail: atuccic@ig.com.br

\begin{abstract}
Natural waters may play the role of sinks or carbon dioxide $\left(\mathrm{CO}_{2}\right)$ emitters, depending on the physicochemical characteristics of the system (diffusion and reaction of this gas into water) as well as on the $\mathrm{pH}$, and the primary production of microorganisms as a result of the consumption of such compounds. Evidence suggests that the $\mathrm{CO}_{2}$ concentrations in ponds are mainly governed by the aquatic metabolism, i.e. by the balance between respiration and photosynthesis; Aim: The purpose of this study was to describe aspects of the metabolism of tilapia cultivation based on the dynamic and balance of the oxygen concentrations (DO) and forms of dissolved inorganic carbon (DIC): carbon dioxide $\left(\mathrm{CO}_{2}\right)$ and bicarbonate $\left(\mathrm{HCO}_{3}^{-}\right)$. Other variables analyzed are: total phosphorus, water transparency, total alkalinity, water temperature, $\mathrm{pH}$, underwater radiation and quantitative analysis of phytoplankton community; Methods: Sampling was collected infor 5 consecutive days from 6:00 AM to 8:00 PM (December/2006) every 2 hours; Results: During the test it was observed periodicity in the fluctuations of the DIC concentrations, being $\mathrm{CO}_{2}$ and $\mathrm{HCO}_{3}$ the predominant fractions. The values of DIC were strongly influenced by the fraction of $\mathrm{CO}_{2}$ and it was observed a predominance of the fraction $\mathrm{HCO}_{3-}$ in the afternoon. $\mathrm{CO}_{2}$ concentrations ranged from $0.48 \mu \mathrm{M}$ through $138.94 \mu \mathrm{M}$, reaching a daily average of $18.04 \mu \mathrm{M}$. The flow of $\mathrm{CO}_{2}$ in the interface atmosphere/water showed variations during the day. In the afternoon (from 12:00 PM until 6:00 PM) the variation pointed to the flow atmosphere/fish pond; however, the balance was $577 \mu \mathrm{mol} . \mathrm{m}^{-2} \cdot \mathrm{h}^{-1}$ in the flow fish pond/atmosphere; Conclusions: The observed dynamics indicated that under the conditions of this study, the metabolism of aquatic organisms was the main driving force of this system, a fact corroborated by the intense process of euthrophication in the pond.
\end{abstract}

Keywords: fish pond, diurnal variation, Nile tilapia, carbon dioxide, water quality, metabolism.

Resumo: As águas naturais podem se comportar como sumidouros ou emissores de dióxido de carbono $\left(\mathrm{CO}_{2}\right)$, dependendo das características físico-químicas do sistema (difusão e reaçôes desse gás na água), como também do $\mathrm{pH}$, e da produção primária dos microorganismos através do consumo desse compostos Evidências apontam que as concentraçóes de $\mathrm{CO}_{2}$ nos lagos sáo principalmente reguladas pelo metabolismo aquático, ou seja, pelo balanço entre a respiração e a fotossíntese; Objetivo: $\mathrm{O}$ presente estudo teve por objetivo descrever aspectos do metabolismo do cultivo de tilápias do Nilo, a partir da dinâmica e do equilíbrio das concentraçôes de oxigênio (OD) e das formas de carbono inorgânico dissolvido (CID): dióxido de carbono $\left(\mathrm{CO}_{2}\right)$ e bicarbonato $\left(\mathrm{HCO}_{3}^{-}\right)$. As demais variáveis analisadas foram: fósforo total, transparência da água, alcalinidade total, temperatura da água, $\mathrm{pH}$, radiação subaquática e análise quantitativa 
da comunidade fitoplanctônica; Métodos: As amostragens ocorreram durante 5 dias consecutivos das 6:00 às 20:00 h (dezembro/2006) em intervalos de $2 \mathrm{~h}$; Resultados: Durante o ensaio foi observada periodicidade nas flutuaçôes das concentraçóes de CID, sendo $\mathrm{CO}_{2}$ e $\mathrm{HCO}_{3}^{-}$, as fraçóes predominantes. Os valores de CID foram fortemente influenciados pela fração $\mathrm{CO}_{2}$ e no período da tarde ocorreu predominância da fração $\mathrm{HCO}_{3}$. As concentraçōes de $\mathrm{CO}_{2}$ variaram de $0.48 \mu \mathrm{M}$ a $138.94 \mu \mathrm{M}$, com concentração média diária de $18,04 \mu \mathrm{M}$. Os fluxos de $\mathrm{CO}_{2}$ na interface água atmosfera mostraram variaçôes ao longo do dia. No período da tarde (12:00 h às 18:00 h) ocorreram no sentido atmosfera/viveiro, entretanto, o balanço foi de $576.7 \mu \mathrm{mol} . \mathrm{m}^{-2} \cdot \mathrm{h}^{-1}$ no sentido viveiro/ atmosfera; Conclusóes: A dinâmica observada indicou que nas condiçóes deste estudo, o metabolismo dos organismos aquáticos foi a principal função de força desse sistema, fato corroborado pelo intenso processo de eutrofização do viveiro.

Palavras-chave: piscicultura, variação diurna, tilápias do Nilo, gás carbônico, qualidade da água, metabolismo.

\section{Introduction}

Natural waters may play the role of sinks or carbon dioxide $\left(\mathrm{CO}_{2}\right)$ emitters, depending on the physicochemical characteristics of the system (diffusion and reaction of this gas into water) as well as on the $\mathrm{pH}$, and the primary production of microorganisms as a result of the consumption of $\mathrm{CO}_{2}$. Evidence suggests that the $\mathrm{CO}_{2}$ concentrations in ponds are mainly governed by the aquatic metabolism, i.e. by the balance between respiration and photosynthesis (Marotta, 2006). The complexity of the process, that presents very different kinetics, results in oversaturated or unsaturated waters in relation to the gas concentration in the atmosphere, that is, presents a non-balanced condition.

Under aerobic conditions, the metabolism of an ecosystem can be expressed in a simplified way by the following equation, which describes the production processes from left to right and the process of mineralization from right to left (Carmouze, 1994) (Equation 1).

$\mathrm{CO}_{2}+\mathrm{H}_{2} \mathrm{O} \longleftrightarrow \mathrm{CH}_{2} \mathrm{O}+\mathrm{O}_{2}$

Carbon dioxide $\left(\mathrm{CO}_{2}\right)$ is generally combined with other compounds into the water. Depending on the $\mathrm{pH}, \mathrm{CO}_{2}$ reacts against water to form equilibrium.

The hypothesis of the present study was based that the mechanisms of interaction between biotic and abiotic compartments, which occur in fish ponds in tropical countries, are highly influenced by the photoperiod. Therefore the purpose of this study was to describe the diurnal dynamic of dissolved oxygen and inorganic carbon forms in a fish pond of Nile Tilapia.

\section{Material and Methods}

The experiment was developed at Agencia Paulista de Tecnologia dos Agronegócios - APTA, Regional
Vale do Paraíba, district of Pindamonhangaba, located at $22^{\circ} 55^{\prime} 50^{\prime \prime} \mathrm{S}$ and $45^{\circ} 27^{\prime} 22^{\prime \prime} \mathrm{W}$, in the State of São Paulo.

The target of this analysis was a fish pond dimensioned as follows: $33 \times 50 \mathrm{~m}$, superficial area of $1,500 \mathrm{~m}^{2}$, and average depth of $1.0 \mathrm{~m}$.

A total of 3,750 Nile tilapia (Oreochromis niloticus Linnaeus, 1758) were introduced into the pond. The first population occurred on 20 October 2006 with 2,585 individuals (average weight $=118.15 \mathrm{~g}$ ) and the second one happened on 23 October 2006with 1,166 individuals (average weight $=262.86 \mathrm{~g}$ ). On December $6^{\text {th }}, 2006$, due to bird attacks the estimated figure pointed to 3,500 fish and average weight of $335.32 \mathrm{~g}$.

Feed was based on the population biomass and maturity phase, considering a rate of $2 \%$ of the fish average weight, or $23.5 \mathrm{~kg}$ of extruded ration daily, twice a day.

Samples were taken from December $16^{\text {th }}$ until December 20 ${ }^{\text {th }}, 2006$ (rainy/hot summer) in order to consider higher temperatures and extended photoperiod. Everyday and every two hours from 6:00 AM until 8:00 PM samples were taken from the pond water column subsurface with a Van Dorn bottle.

The following variables were analyzed: total phosphorus (method described in Valderrama, 1981), water transparency (by Secchi disc), total alkalinity (method described in APHA, 1992), water temperature, dissolved oxygen and $\mathrm{pH}$ (multisound Horiba U-22) and underwater radiation (light meter model Data logger LI - 1400).

In order to determine the concentration of DIC

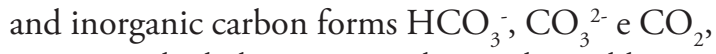
it was applied the existing chemical equilibrium concept for these forms of inorganic carbon. Such equilibrium is sensitive to alkalinity, water 
temperature and $\mathrm{pH}$, according to the method described by Wetzel and Likens (1991), as per the Equations 2, 3, 4 and 5:

$\mathrm{Alc}=\operatorname{DIC}\left\{\begin{array}{l}\left(\frac{\left[\mathrm{H}^{+}\right]}{\mathrm{K}_{1}}+1+\frac{\mathrm{K}_{2}}{\left[\mathrm{H}^{+}\right]^{2}}\right)-1+ \\ {\left[2\left(\frac{\left[\mathrm{H}^{+}\right]^{2}}{\mathrm{~K}_{1} \mathrm{~K}_{2}}+\frac{\left[\mathrm{H}^{+}\right]}{\mathrm{K}_{2}}+1\right)-1\right]+\left[\mathrm{OH}^{-}\right]-\left[\mathrm{H}^{+}\right]}\end{array}\right\}$

$\mathrm{CO}_{2}{ }^{*}=\operatorname{DIC}\left(1+\frac{\mathrm{K}_{1}}{\left[\mathrm{H}^{+}\right]}+\frac{\mathrm{K}_{1} \mathrm{~K}_{2}}{\left[\mathrm{H}^{+}\right]^{2}}\right)^{-1}$

$\mathrm{HCO}_{3}{ }^{-}=\mathrm{DIC}\left(\frac{\left[\mathrm{H}^{+}\right]}{\mathrm{K}_{1}}+1+\frac{\mathrm{K}_{2}}{\left[\mathrm{H}^{+}\right]^{2}}\right)^{-1}$

$\mathrm{CO}_{3}{ }^{-}=\mathrm{DIC}\left(\frac{\left[\mathrm{H}^{+}\right]^{2}}{\mathrm{~K}_{1} \mathrm{~K}_{2}}+\frac{\left[\mathrm{H}^{+}\right]}{\mathrm{K}_{2}}+1\right)^{-1}$

where: Alc $=$ Alkalinity in eq. $\mathrm{L}^{-1} ; \mathrm{DIC}=$ Dissolved Inorganic Carbon in mol. $\mathrm{L}^{-1} ; \mathrm{K}_{1}$ and $\mathrm{K}_{2}$ are the dissociation constants of $\mathrm{H}_{2} \mathrm{CO}_{3}$.

Equation Van' Hoff (Equation 6) was used for calculating the dissociation constants $\left(\mathrm{K}_{1} \mathrm{e} \mathrm{K}_{2}\right)$ because they are sensitive to temperature (according to Le Chatelier concept) (Atkins and De Paula 1999).

$\mathrm{K}=\mathrm{K}^{\theta} \exp \left[\frac{\Delta \mathrm{H}}{\mathrm{R}}\left(\frac{1}{\mathrm{~T}}-\frac{1}{\mathrm{~T}^{\theta}}\right)\right]$

where: $\mathrm{K}^{\theta}=$ dissociation constant of $\mathrm{H}_{2} \mathrm{CO}_{3}$ at $25^{\circ} \mathrm{C} ; \mathrm{K}=$ dissociation constant of $\mathrm{H}_{2} \mathrm{CO}_{3}$ adjusted by temperature; $\Delta \mathrm{H}=$ dissociation enthalpy of $\mathrm{H}_{2} \mathrm{CO}_{3} ; \mathrm{R}=$ gases constants; $\mathrm{T}=$ water temperature in Kelvin; $\mathrm{T}^{\theta}=298.16^{\circ} \mathrm{K}$;

$\mathrm{CO}_{2}$ and $\mathrm{OD}$ flow through water/air interface was estimated considering the model of stagnating film applying the law of Fick and the empiric Equations 7 and 8 proposed by Almeida et al. (2001) and Crusius and Wanninkhof (2003).

$\mathrm{F}=\mathrm{K}{ }_{\mathrm{X}}\left(\mathrm{pX}^{\mathrm{aq}}-\mathrm{pX}^{\mathrm{at}}\right)$

$\mathrm{K}_{\mathrm{X}}=0.72 \mu\left(\frac{600}{S_{\mathrm{c}}}\right)^{2 / 3}$

where: $\mathrm{F}=$ flow of gas within the interface water/ air; $\mathrm{K}_{\mathrm{x}}=$ Constant of gas transference; $\mathrm{pX}^{\mathrm{aq}}=$ partial pressure of gas into the aqueous environment; $\mathrm{pX}^{\mathrm{at}}$ $=$ partial pressure of gas into atmosphere; $\mu=$ wind velocity; $\mathrm{Sc}=\mathrm{Schmidt}$ number. For this study it was adopted a wind velocity equal to $3 \mathrm{~m} \cdot \mathrm{s}^{-1}$.

For the quantitative analysis of phytoplankton community, samples were collected at the subsurface with the Van Dorn bottle and stabilized with 1\% acetic Lugol. The counting of individuals was conducted in accordance with Utermöhl (1958).
Statistical analyses were performed using the software StatSoft Statistica v6. For statistical analysis ANOVA and linear correlations it was considered the significance level of 0.05 .

\section{Results and Discussions}

The dissolved inorganic carbon (DIC) presented an average value of $1.81 \mathrm{mM}$ with a standard deviation of $1.44 \mathrm{mM}$ over the five days of sample campaign, reaching a maximum of $7.0 \mathrm{mM}$ (Table 1). During the test frequent fluctuations in the concentrations of DIC (ANOVA $p=0.57$ ) were observed.

The predominant forms of DIC were carbon dioxide $\left(\mathrm{CO}_{2}\right)$ and bicarbonate ion $\left(\mathrm{HCO}_{3}^{-}\right)$, and the values of DIC were strongly influenced by the fraction $\mathrm{CO}_{2}$ as shown in Figure 1a, presenting a strong linear correlation $\left(\mathrm{r}^{2}=+0.999\right)$. In the morning, between 6:00 AM and 8:00 AM, it was observed the lowest incidence of underwater radiation and the highest values of $\mathrm{CO}_{2}(\mathrm{p}<0.05$, correlation type Gamma) - Figures $2 \mathrm{a}$ and $3 \mathrm{~b}$. During the day, with the increased incidence of underwater radiation, there were reductions in the concentration of DIC and change in the predominant forms of carbon, and the fraction of $\mathrm{HCO}_{3}$ - was predominant with relevant reduction in the availability of $\mathrm{CO}_{2}$ according to Figure $1 \mathrm{~b}$.

It can be said that the changes observed in the above variables were associated with the increased photosynthetic activity in the fish pond. Some authors emphasize that the main factors influencing the development of phytoplankton community are light and temperature (Rangel-Yagui et al., 2004; Danesi et al., 2004; Morist et al., 2001), showing a dependence of photosynthetic rate and light intensity. Jensen \& Kutsen (1993) observed that high levels of light intensities are responsible for two phenomena: photo-inhibition, which results in a decrease in the maximum yield of growth, and the photo-oxidation, which causes lethal effects to the cell. In this study the consumption of DIC accompanied the light intensity, independent of the level of intensity and inclination angle, thus indicating that the characteristics associated with water transparency attenuated the effect of radiation. This was corroborated by the inverse variation of $\mathrm{OD}$ concentration and $\mathrm{pH}$ values in relation to DIC, $\mathrm{r}^{2}=-0.69$ and $\mathrm{r}^{2}=-0.71$, respectively. Kayombo et al. (2002) and Robson (2005) observed direct relations between the daily cycle of light intensity, and the $\mathrm{pH}$ and dissolved oxygen. Some relations observed by Tadesse, Green 


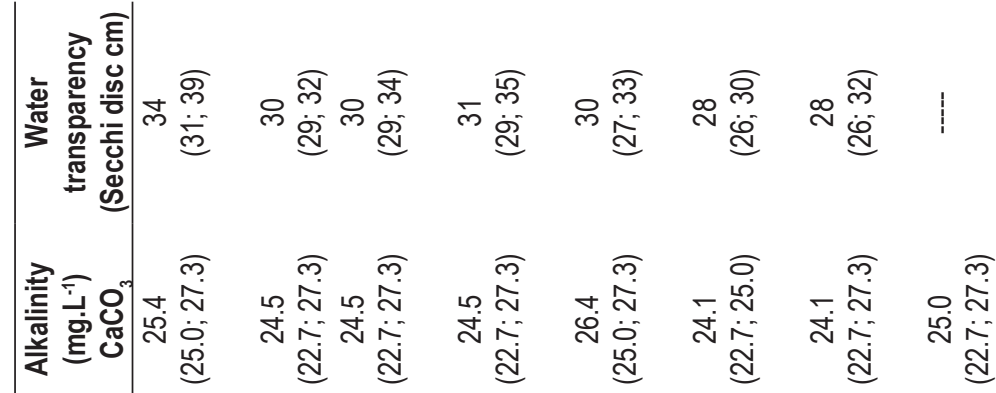

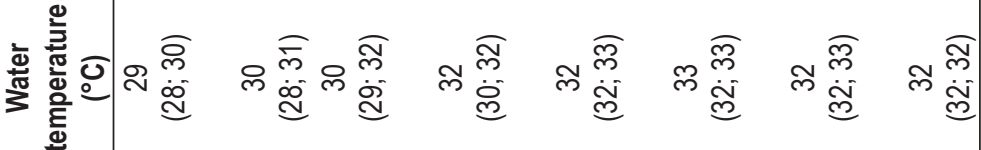

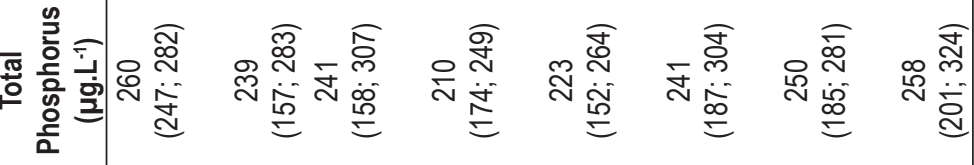

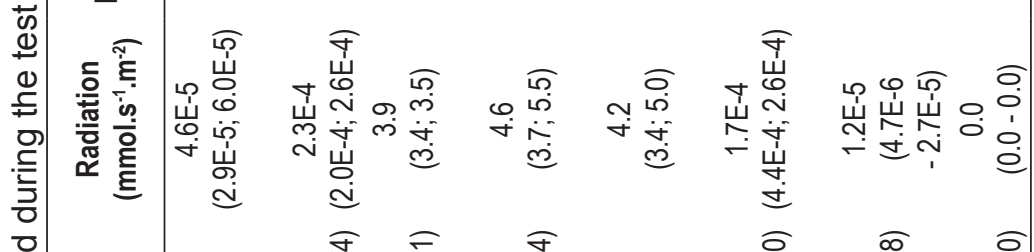

I

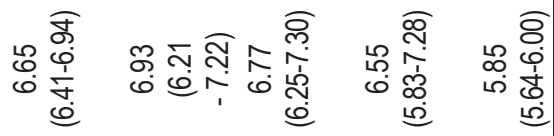

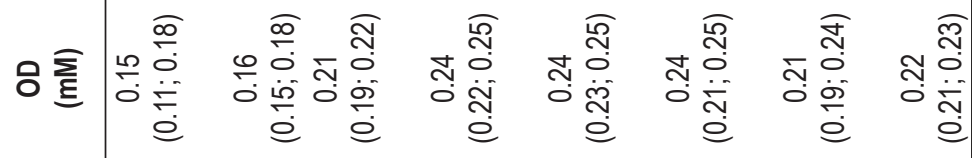

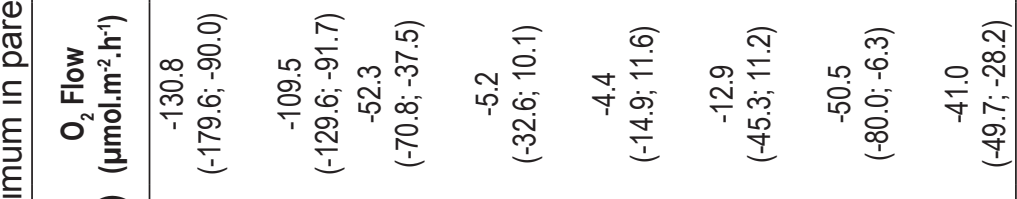

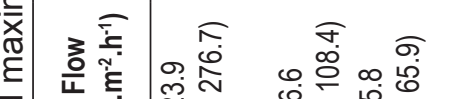

至

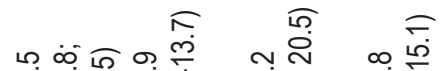

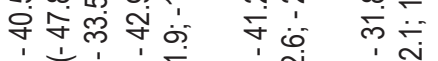

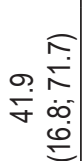

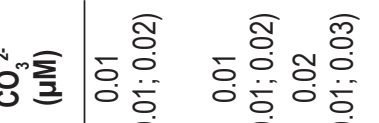

웜

芒

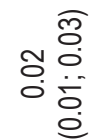

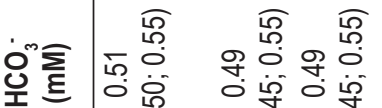

守

婴 क्م

药

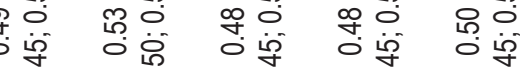

$\widetilde{a} \widehat{\bar{x}}$

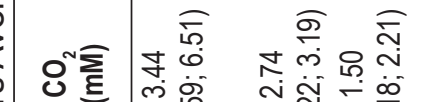

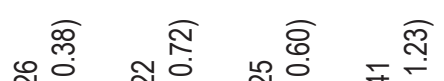

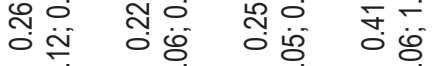

กำ

¿ $\stackrel{0}{0}$

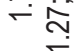

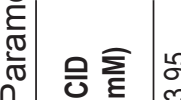

ล $\widehat{0}$

\% $\widehat{a}$ o

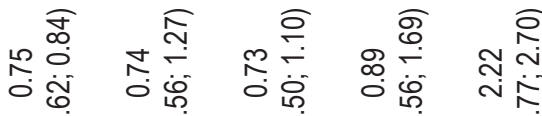
ले ले ले

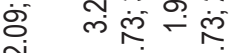

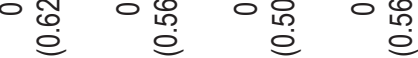

N

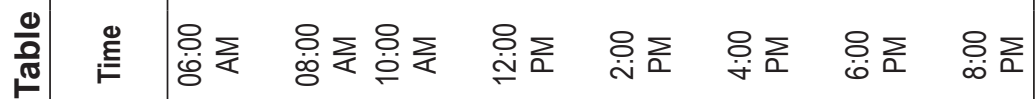



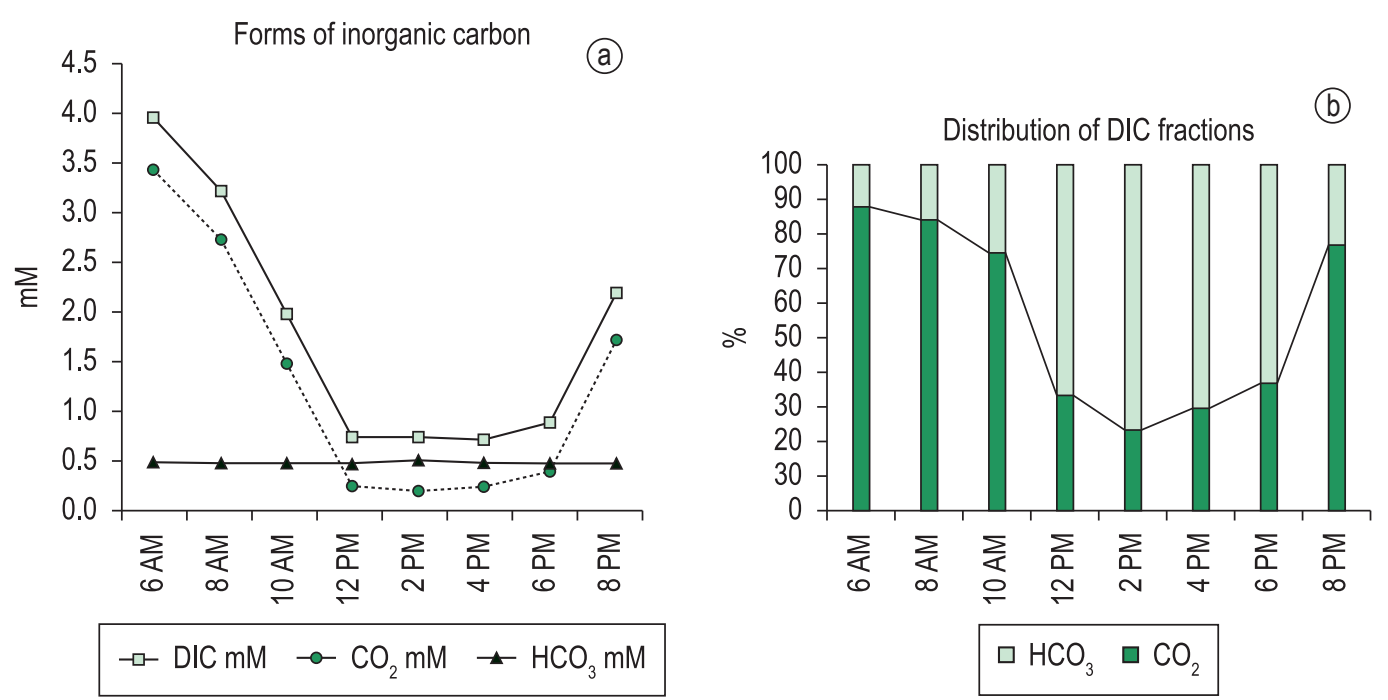

Figure 1. Diurnal variations in the forms of inorganic carbon. DIC values are highly influenced by fraction $\mathrm{CO}_{2}$, (a), however fraction $\mathrm{HCO}_{3-}$ prevails in the period between 12:00 PM and 6:00 PM.

and Puhakka (2004), related diurnal variations of dissolved oxygen, $\mathrm{pH}$ and inorganic carbon to the biological activities (respiration and photosynthesis).

The fraction of $\mathrm{HCO}_{3}$ - presented low variability throughout this study, where $78 \%$ of the data ranged from 0.45 to $0.51 \mathrm{mM}$. In order to meet the demand of carbon even in periods when the $\mathrm{CO}_{2}$ concentration was lower than that of $\mathrm{HCO}_{3}^{-}$(between 12:00 PM and 4:00 PM), the photosynthetic community would be expected to present a reduction in the bicarbonate concentration due to the shift in the balance of the inorganic carbon forms (chemical Equation 9). Wetzel (1993) argued that phytoplankton uses the $\mathrm{HCO}_{3}^{-}$when its concentration is higher than that of $\mathrm{CO}_{2}$ by more than 10 times. During the present study such condition was presented on the first day at 04:00pm and 06:00pm, and at 02:00pm on the second day; however it was not observed a reduction in the fraction of $\mathrm{HCO}_{3}$. This can be explained by the flow of invasive atmospheric $\mathrm{CO}_{2}$ that met the needs of carbon of the photosynthetic community as shown in Figure $2 \mathrm{~b}$.

$\mathrm{HCO}_{3}^{-}+\mathrm{H}^{+} \leftarrow \mathrm{CO}_{2}+\mathrm{H}_{2} \mathrm{O}$

The concentration of DIC showed deviations from the thermodynamic equilibrium conditions, according to Henry's Law, and the values were higher in the morning (between 6:00 AM and 10:00 AM) and lower in the afternoon (between 12:00 PM and 6:00 PM), considering a partial $\mathrm{CO}_{2}$ pressure of 35.34 matm in the atmosphere (Figure 2a). During the sampling campaign the balance between DIC and the equilibrium values was positive $(31.0 \mathrm{mM})$ and the estimated balance of the $\mathrm{CO}_{2}$ flow between the interface water/air was $577 \mu \mathrm{mol} . \mathrm{m}^{-2} \cdot \mathrm{h}^{-1}$, thus following the behavior of $\mathrm{DIC}$ as shown at Figure 2b. According to Marotta (2006) the aquatic heterotrophic metabolism is characterized by breathing rates higher than the primary production ones, tending to produce a super saturation of $\mathrm{CO}_{2}$ and liquid release of this gas to the atmosphere.

Almeida et al. (2001) when assessing the flow of $\mathrm{CO}_{2}$ into the lake Taquaral, a hypereutrophic artificial lake located in the city of Campinas in Sao Paulo, found values of 105, 116 and $142 \mu \mathrm{mol} . \mathrm{m}^{-2} \cdot \mathrm{h}^{-1}$ at 6:30 AM, 10:45 AM and 3:30 PM respectively. The same author investigating the diurnal variation of $\mathrm{CO}_{2}$ in the lake Oleo, a marginal pond at River Mogi Guaçu in Sao Paulo, got average values of $-1,081$ and $-3,383 \mu \mathrm{mol} \cdot \mathrm{m}^{-2} \cdot \mathrm{h}^{-1}$ in October 1997 and March 1998, respectively, and concluded that there were no significant differences in emissions throughout the day. Regarding the atmosphere, the studied fish pond presented periods of $\mathrm{CO}_{2}$ saturation and non-saturation throughout the day, most likely influenced by photosynthetic activity.

Almeida et al. (2001) discussed the study of Cole (1994), which after evaluating 1,835 lakes around the world found that with regards to the atmosphere $87 \%$ were saturated with $\mathrm{CO}_{2}$ and $7 \%$ were in equilibrium. Marotta (2006) by referring to the same study of Cole said that the escape of carbon like $\mathrm{CO}_{2}$ from lakes into the atmosphere is about $70 \mathrm{gm}^{-2} \cdot$ year ${ }^{-1}$, or approximately $180 \mu \mathrm{mol} \cdot \mathrm{m}^{-2} \cdot \mathrm{h}^{-1}$. 
During this test the fluctuation of the concentration of DO occurred in a cyclic way, (ANOVA $p=0.39)$. DO concentrations remained below the equilibrium values most of the time. In the period between 12:00 PM and 4:00 PM it was observed the best value close to equilibrium, and the peaks of underwater radiation occurred at similar hours (from 10:00 AM until 2:00 PM) as per Figures $2 \mathrm{~b}$ and $2 \mathrm{c}$, showing a linear correlation $\mathrm{r}^{2}=+0.45$. The solubility of gases is inversely proportional to temperature. In the present study it was observed an opposite behavior, where the highest values of DO were related to the highest temperature $\left(r^{2}=+0.60\right)$, a fact also observed in the work of Sipaúba-Tavares and Colus (1995).

It can be argued that changes in $\mathrm{pH}$ and $\mathrm{DO}$ values are related to the phytoplankton community. According to Durigan et al. (1992), there is a directly proportional relationship between dissolved oxygen (DO) and total pigments (chlorophyll- $a$ and pheophytin) because photosynthesis occurs in the course of the day photoperiod. Sipaúba-Tavares (1996) when studying fish ponds found diurnal variations in $\mathrm{DO}$ concentrations and $\mathrm{pH}$ correlated positively with the concentration of total pigments.

Mainardes-Pinto and Mercante (2003) reported an inverse relationship between chlorophyll-a and the values of water transparency. The highest values of water transparency were found in the morning. The increasing radiation causes a decrease in these values (Table 1). In previous studies under similar conditions (Mercante et al., 2007) the authors obtained measures of chlorophyll-a constantly exceeding $0.030 \mathrm{mg} . \mathrm{L}^{-1}$ by estimating the biomass of phytoplankton. This result showed a cause/effect relationship, i.e. the supply of nutrients by the feeding process promoted the algae growth. During the production of tilapia, the fish pond remained eutrophic with total phosphorus concentrations often above $200 \mu \mathrm{g} . \mathrm{L}^{-1}$. This reinforces the idea
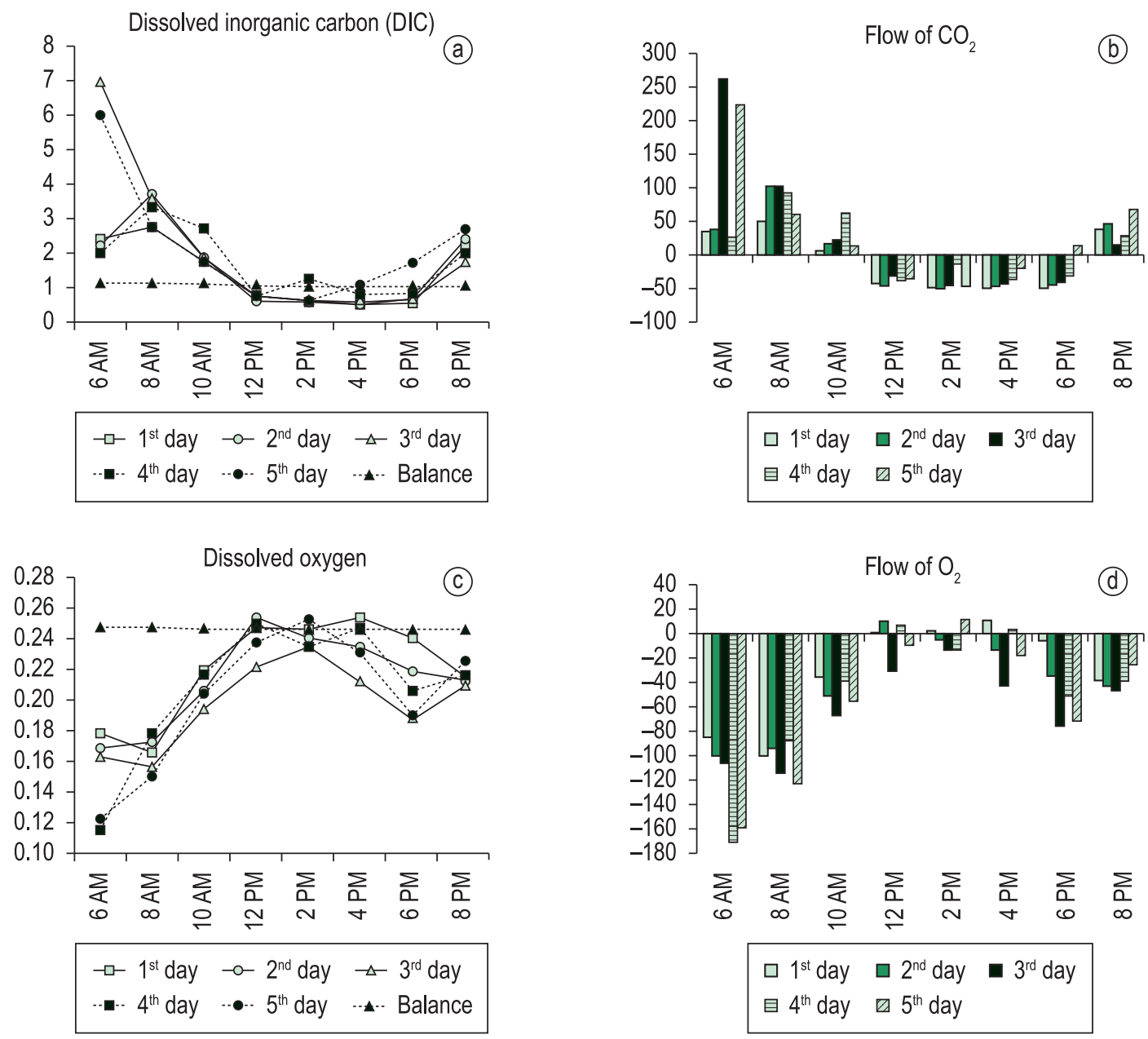

Figure 2. Diurnal variation in the concentrations of dissolved gases, their theoretical equilibrium value and respective flows in the interface water/atmosphere. 

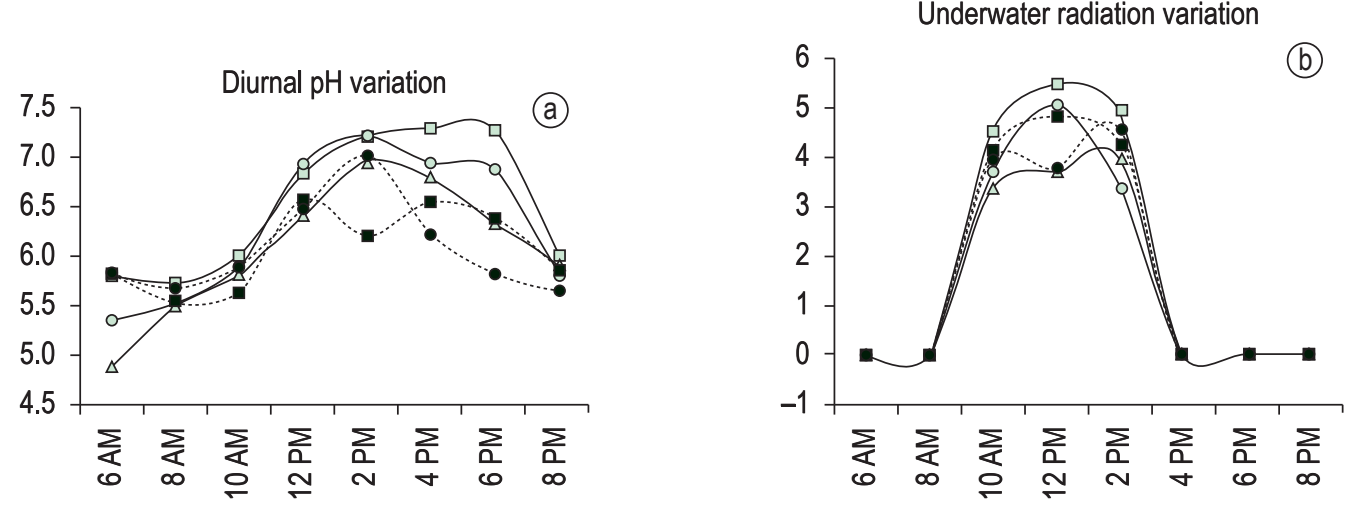

$$
\rightarrow-1^{\text {st }} \text { day } \quad \rightarrow-2^{\text {nd }} \text { day } \quad \triangle 3^{\text {rd }} \text { day } \quad \cdots \cdots 4^{\text {th }} \text { day } \quad \cdots \bullet 5^{\text {th }} \text { day }
$$

Figure 3. Diurnal $\mathrm{pH}$ and underwater radiation variations.

that the dynamics of the studied fish pond is highly influenced by the photosynthetic dynamics. Quantitative analysis of phytoplankton community showed that Chlorophyceae and Cyanobacteria contributed significantly to the richness and density of phytoplankton (>35.000 org. $\mathrm{mL}^{-1}$ ). Chlorophyceae, which was very significant in terms of species richness in this study, is referred by other authors as the group that contributes most to the total richness of phytoplankton in Brazilian eutrophic tropical waters (Bicudo et al., 1999, Pinto-Coelho et al., 1999, Sant'Anna et al., 1997, Tucci et al., 2006). This result showed that phytoplankton supports the photosynthetic dynamics in the fish pond.

\section{Conclusion}

A fish pond is an eutrophic environment to facilitate the increase of productivity in the fish production system. The activity of phytoplankton in lentic and eutrophic environments exerts a strong influence on the dynamics of dissolved gases in the atmosphere driven by the light availability. Thus, the observed variations in oxygen concentrations, the $\mathrm{pH}$ and dissolved inorganic carbon forms indicated that one of the major driving functions of the system was the underwater radiation that conditioned the metabolism of photosynthetic organisms. We can infer that the studied fish pond, despite being a man-made system of fish production, has maintained a predictable dynamic for lentic, shallow and eutrophic aquatic systems depending on the metabolism associated with the primary production.

\section{Acknowledgements}

To FAPESP for financing project 2005/03011-7.
To Agencia Paulista de Tecnologia dos Agronegócios - APTA, Vale do Paraíba Regional Office, represented by Dra Cleide Shimidt Romeiro Mainardes Pinto.

To MSc Jeniffer Sati Pereira from the Water Resources Laboratory at Instituto de Pesca, for the support received during the laboratory tests.

To MSc. Claudio Cazal de Araujo Lira Filho, for the assistance in the data processing and pertinent discussions.

To Luiz Claudio dos Santos Evangelista, for the support in the laboratory and field research.

\section{References}

ALMEIDA, FV., GUIMARÃES, JR. and JARDIMA, WF. 2001. Measuring the $\mathrm{CO}_{2}$ flux at the air/water interface in lakes using flow injection analysis. Jornal Environment Monitor, vol. 3, p. 317-321. PMid:11432270. doi:10.1039/b010065j

American Public Health Association - APHA. 1992. Standard methods for the examination of water and wastewater. 20th ed. Washington: United Book Press.

ATKINS, P. and DE PAULA, J. 1999. Físico-quimica. 6th ed. Rio de Janeiro: Editora LTC. 252 p. vol. 1.

BICUDO, CEM., RAMÍREZ, RJ., TUCCI, A. and BICUDO, DC. 1999. Dinâmica de populaçôes fitoplanctônicas em ambiente eutrofizado: o Lago das Garças, São Paulo. In HENRY, R. (Ed.). Ecologia de reservatórios: estrutura, função e aspectos sociais. Botucatu: FUNDIBIO/FAPESP. p. 451-507.

CARMOUZE, JP. 1994. O metabolismo dos ecossistemas aquáticos continentais: fundamentos teóricos métodos de estudos e análises química. São Paulo: Edgard Blücher, FAPESP. 254 p.

COlE, J. J., CARACO, N. E., KLING, G. W., AND KRATZ., T. K. 1994. Carbon dioxide 
supersaturation in the surface waters of lakes. Science, 265, p. 1568-1570.

CRUSIUS, J. and WANNINKHOF, R. 2003. Gas transfer velocities measured at low wind speed over a lake. Limnology Oceanography, vol. 48, no. 3, p. 1010-1017. doi:10.4319/lo.2003.48.3.1010

DANESI, EDG., RANGEL-YAGUI, CO., CARVALHO, JCM., CARVALHO, JCM. and SATO, S. 2004. Effect of reducing the light intensity in the growth and production of chlorophyll by Spirulina platensis. Biomass Bioenergy, vol. 26, p. 329-335. doi:10.1016/ S0961-9534(03)00127-2

DURIGAN, JG., SIPAÚBA-TAVARES, LH. and OLIVEIRA, DBS. 1992. Estudo limnológico em viveiros de psicultura. Parte I: variação nictimeral de fatores físicos químicos e biológicos. Acta Limnologica Brasiliensis, vol. 4, p. 211-223.

KAYOMBO, S., MBWETTE, TSA., MAYO, AW., KATINA, JHY., JORGENSEN, SE. 2002. Diurnal cycles of variation of physical-chemical parameters in waste stabilization ponds. Ecological Engineering, vol. 18, p. 187-291. doi:10.1016/S09258574(01)00086-6

MAINARDES-PINTO, CSR. and MERCANTE, CTJ. 2003. Avaliação de variáveis limnológicas e suas relaçóes com uma floração de Euglenaceae pigmentada em viveiros povoados com tilápia do Nilo (Oreochromis niloticus - Linnaeus), São Paulo, Brasil. Acta Scientiarum. Biological Sciences, vol. 25, no. 2, p. 323-328.

MAROTTA, H. 2006. Os fatores reguladores do metabolismo aquático e sua influência sobre o fluxo de dióxido de carbono entre os lagos e a atmosfera. Oecologia Brasiliensis, vol. 10, no. 2, p. 177-185. doi:10.4257/oeco.2006.1002.05

MERCANTE, CTJ., MARTINS, KY., CARMO, CF., OSTI, JS. , MAINARDES-PINTO, CSR. and TUCCI, A. 2007. Qualidade da água em viveiro de Tilápia do Nilo (Oreochromis niloticus):caracterização diurna de variáveis fisicas, quimicas e biologicas, São Paulo, Brasil. Bioikos, vol. 21, no. 2, p. 79-88.

MORIST, A., MONTESINOS, JL., CUSIDÓ, JA. and GÒDIA, F. 2001. Recovery and treatment of Spirulina platensis cells cultured in a continuous photobioreactor to be used as food. Process Biochemistry, vol. 3, p. 535-547. doi:10.1016/ S0032-9592(01)00230-8
PINTO-COELHO, RM., COELHO, MM., ESPÍRITOSANTO, MM. and CORNELISSEN, TG. 1999. Efeitos da eutrofização na estrutura da comunidade planctônica na Lagoa da Pampulha, Belo Horizonte, MG. In HENRY, R. (Ed.). Ecologia de reservatórios: estrutura, função e aspectos socias. Botucatu: FUNDIBIO/FAPESP. p. 551-572.

RANGEL-YAGUI, CO., DANES, EDG., CARVALHO, JCM., SATO, S. 2004. Chlorophyll production from Spirulina platensis: cultivation with area addition by fed-batch process. Bioresource Technology, vol. 92, p. 133-141. doi:10.1016/j.biortech.2003.09.002

ROBSON, B.J. 2005. Representing the effects of diurnal variations in light on primary production on seasonal time-scale. Ecological Modelling, vol. 186, p. 358-365. doi:10.1016/j.ecolmodel.2005.01.033

SIPAÚBA-TAVARES, LH. 1996. Variação diurna de alguns parâmetros limnológicos em três viveiros de piscicultura submetidos a diferentes tempos de residência. Acta Limnologica Brasiliensis, vol. 8, p. 29-36.

SIPAÚBA-TAVARES, LH. and COLUS, DSO. 1995. Estudo da variação nictimeral em um viveiro de piscicultura no período de seca. Revista UNIMAR, vol. 17 , no. 2, p. 225-236.

TADESSE, I., GREEN, F. B. and PUHAKKA J. A. 2004. Seasonal and diurnal variations of temperature, $\mathrm{pH}$ and dissolved oxygen in advanced integrated wastewater pond system treating tannery effluent. Water Research, vol. 38, p. 645-654.

TUCCI, A., SANT'ANNA, CL., GENTIL, RC. and AZEVEDO, MTP. 2006. Fitoplâncton do Lago das Garças, São Paulo, Brasil: um reservatório urbano eutrófico. Hoehnea, vol. 33, p. 147-175.

UTERMÖHL, H. 1958. Zur Vervolkommung der quantitativen phytoplankton: methodik. Mitteilungen Internationale Vereinigung für Theoretische und Angewandte Limnologie, vol. 9, p. 1-38.

VALDERRAMA, JC. 1981. The simultaneous analysis of total nitrogen and phosphorus in natural water. Marine Chemistry, vol. 10, p. 109-122. doi:10.1016/0304-4203(81)90027-X

WETZEL, RG. 1993. Limnologia. Lisboa, Portugal: Editora Fundação Calouste Gulbenkian. 914 p.

WETZEL, RG., and LIKENS, GE. 1991. Limnological Analyses. 2th ed. USA: Ed. Springer-Verlag. 391 p.

Received: 23 June 2010 Accepted: 20 March 2011 